\title{
Optimization of Location Permit Application Services Through Online Single Submission System
}

\author{
Edi Rohaedi; Nandang Kusnadi; Teguh Setiadi; Eka Ardianto Iskandar \\ Lecturers of Bachelor of Law Program, Faculty of Law, Universitas Pakuan, Indonesia \\ http://dx.doi.org/10.18415/ijmmu.v8i12.3356
}

\begin{abstract}
The government took the policy of applying for location permits through the Online Single Submission system to improve the national economy. This research aims to determine the arrangement and implementation of location permit application services through Online Single Submission. The nature of this research is normative juridical, methods used descriptive analytically with qualitative approaches, and data collection is done through literature studies and interviews. The results showed that the implementation of location permit application services through the Online Single Submission system has not been optimal because there are still specific permissions that require direct interaction with related agencies, as well as the difficulty of access through the Online Single Submission system at the Land Office in the process of issuing location permits integrated on the Online Single Submission system.
\end{abstract}

Keywords: Application Services; Location Permissions; Single Submission Online

\section{Introduction}

Application services in the field of licensing through the Online Single Submission system by the government were first launched in 2018. This system aims to simplify the licensing process as mandated in Presidential Regulation No. 91, 2017. This online single submission licensing service is an attempted licensing system integrated electronically with all ministries/state institutions to local governments in Indonesia. One form of government commitment in improving the ease of doing business rating in Indonesia is to issue Presidential Regulation No. 91 of 2017 on Accelerating The Implementation of Efforts, followed by Government Regulation No. 24 of 2018 on Licensing Services Trying to Integrate Electronically or Online Single Submission (OSS) (Sanjoyo et al., 2020).

The government took the licensing service policy through the Online Single Submission system to improve the national economy (Sanjoyo et al., 2020). This service policy can affect the growth of the business world, which has been complaining about the length of time and bureaucratic chain, including in the Service of issuing location permits. Location permit is a requirement that needs to be met by business actors who will obtain land in the framework of investment to direct and control business actors in acquiring land, considering that land tenure must pay attention to the interests of many communities. Land use must be following the applicable spatial plan and with the physical capabilities of the land (Hasni, 2008). 
Location Permit is a permit given to business actors to obtain land necessary for their business or activities and also applies as a permit for the transfer of rights and to use the land for business purposes or actions in the provisions of Article 1 number 1 of the Regulation of the Minister of Agrarian Affairs and Spatial Planning / Head of the National Land Agency of the Republic of Indonesia No. 17 year 2,019.

Location permits and technical considerations of land are essential in improving governance in licensing in the business field. Hal tersebut merupakan indikator penilaian daya saing di Indonesia dalam memberikan kemudahan berinvestasi. Oleh karena itu, langkah penting yang dapat diambil pemerintah untuk kemudahan berbisnis adalah mereformasi peraturan perizinan terkait akuisisi atau perdagangan di Indonesia.For this reason, licensing regulation reform, including the application service of location permits, is one of Indonesia's agendas in improving the quality of regulations (Mayasari, 2019).

However, implementing the location permit application service through single online submission is still not optimal. This is due to the difficulty of access to the Online Single Submission system that has not been supported by the availability of adequate land computerized equipment or devices at the Land Agency / Office in the process of issuing location permits integrated on the Online Single Submission system. This condition has an impact on the resulting product is in manually made location permit maps, not digital products as required in the legislation.

In addition, the location licensing service system through the Online Single Submission system is still a problem related to its governance both at the central government level and at the regional level. This system has not been fully integrated with the licensing system in ministries and state institutions at the mid-level. Meanwhile, many local governments still perform location permit services at the regional level through the application-based regional licensing system independently.

\section{Research Methods}

This type of research uses an empirical juridical type. Normative juridical type refers to legal norms and legal principles in-laws and legal norms that live in society. At the same time, the practical juridical approach is how the Rule of Law is applied in the community. The method used is descriptiveanalytical with a qualitative approach, and data collection is done through literature studies and interviews at the Bogor City Land Office.

\section{Results and Discussions}

\section{Understanding Location Permissions}

In the spatial arrangement system, licensing is one of the instruments of controlling the utilization of space which is in principle an instrumental preventive that contains juridical aspects consisting of prohibitions, approvals that are the basis of exceptions, and provisions in granting permits. Article 35 Related Article 37 paragraph (1) of Law No. 26 of 2007 stipulates that control of space utilization is carried out by establishing zoning regulations, licensing, incentives and disincentives, and the imposition of sanctions.

Permission is an instrument in administrative law that regulates and controls the ruler against community activities (Asiyah, 2017). In addition, permits can provide legal certainty for government actions and legal protection for permit holders. Permission (in the narrow sense) is an agreement of the ruler based on government laws or regulations to, in certain circumstances, deviate from the provisions of the prohibition of legislation (Spelt et al., 1993). 
Furthermore, Tatiek Sri Djatmiati (2005) said that permission is a legal means used by the government to control people's lives to avoid deviating from the provisions of applicable law. Permits are also juridical instruments used by the government in community service (Asiyah, 2017). While in Article 1 number 1 of Law No. 30 of 2014, the permit is defined as the decision of authorized government officials as a form of approval for the application of citizens by the provisions of the laws and regulations.

Space utilization licensing instruments play an essential role in a spatial arrangement in Indonesia. Space utilization permit is a requirement specified in Law No. 26 of 2007 on Spatial Arrangement to individuals or legal entities as business actors before utilizing space. One form of space utilization permit as defined in Law No. 26 of 2007 is the location permit requirement (Santoso, 2012).

The purpose of location permits concerning controlling the utilization of space is to regulate the utilization of space per the spatial plan set by the government. Government Regulation No. 15 of 2010 on the Implementation of Spatial Arrangements holds further the provisions of location permits. In Article 160 of the Government, Regulation has stipulated that in the utilization of space, everyone must have a license for space utilization and must implement every licensing provision in the implementation of space utilization.

Based on The Provisions of Article 1 number 1 of the Regulation of the Minister of Agrarian Affairs and Spatial Planning / Head of the National Land Agency No. 17 of 2019 determines that the Location Permit is a permit given to business actors to obtain land necessary for their business or activities and also applies as a permit for the transfer of rights and to use the land for business purposes or activities.

Location permit is a requirement that needs to be met by business actors who will obtain land in the framework of investment to direct and control business actors in acquiring land, considering that land tenure must pay attention to the interests of many communities. Land use must be following the applicable spatial plan and with the physical capabilities of the land (Hasni, 2008). Furthermore, Sutedi (2009) asserted, to obtain land for investment purposes, a Location Permit is required before business actors carry out land acquisition activities.

The object of the location permit is a land that, according to the regional spatial plan, has been established its use for business activities based on business activity plans owned by business actors. The business activity plan must be based on granting permits/approvals/registration for investment activities issued by authorized officials in the field of investment as stipulated in the provisions of Article 4 of the Regulation of the Minister of Agrarian Affairs and Spatial Planning No. 17 of 2019. So that the use and utilization of space requested location permits by business actors is not for activities other than their business activities.

The subject of location permits, namely individual or non-individual actors who in running a business need infrastructure in the form of land to support their business activities but do not yet own or control the land. The subject provisions of the location permit are stipulated in Article 6 of the Regulation of the Minister of Agaria and Spatial planning. 17, 2019. Regulation of the Minister of Agrarian Affairs and Spatial Planning No. 17 of 2019 regulates the procedure of issuing location permits divided into 2 (two) different conditions, namely the acquisition of location permits without Commitment and based on Commitment. Location permits without Commitment and based on Commitment have the same that must go through the technical consideration of land within ten days; otherwise, the location permit becomes void. Based on Article 4 paragraph (1) of the Regulation of the Minister of Agrarian Affairs and Spatial Planning No. 15 of 2018, the technical consideration of land in issuing location permits is to contain approval or rejection of location permits. 
Against the issuance of location permits without Commitment, the factor that must be considered is the business location requested to have a digital map of Spatial Detail Plan integrated with Online Single Submission in certain areas and conditions as referred to article 7 paragraph (2) of the Minister of Agrarian Affairs and Spatial Planning No. 17 of 2019.

\section{Location Permit Service Regulations Through Online Single Submission System}

Online Single Submission, better known as OSS, was launched on July 8, 2018, to facilitate the licensing process. The OSS system was first established in Presidential Regulation No. 91 of 2017, while the rules of implementation of this system are regulated in Government Regulation No. 24 of 2018. OSS is an effort to integrate the licensing system electronically with all ministries/institutions $(\mathrm{K} / \mathrm{L})$ of the country to the Local Government (regional government) in Indonesia. The government establishes the licensing policy through the OSS system to improve the national economy. As a result, the business licensing problem that business actors have complained about in starting a business against the length of time and bureaucratic chain can be addressed.

The use of OSS is usually done in terms of the management of business permits by business actors. So if you want to try or have a business can do the administration of this OSS. The effort pioneered is unlimited. The point is that all types of companies can be obtained permission through management on this OSS system (Setiadi et al., 2021). Both micro, small, and medium enterprises to large-scale businesses should get a license to stand and operate in running their businesses. New and long-established companies should take care of OSS before using it. OSS itself has the same meaning as Licensing Trying to Integrate Electronically. So this OSS can also be interpreted as a permit to try, which OSS institutions certainly publish. These attempted permits are issued on ministers and agency leaders or governors, regents, or mayors. This attempted permit is issued to business actors through an integrated electronic system (Prasetio et al., 2021).

With the permission of this authorized institution, it means that the business actor has been approved to set up a business and run your business. Furthermore, just run a company based on applicable rules or policies only. Running a business has also become the right of a person as a business owner to operate freely. People can use capital from anywhere, both within the country and wealth from foreign or foreign parties to support the industry. The use of THIS OSS can provide several benefits, including the first is to facilitate the management of licensing. Business actors should use this OSS to get business licenses more straightforwardly by encouraging business licenses.

Generally, businesses require various permits from various government agencies, including having to have location permits, environmental permits, and building permits. Therefore, you need to use this OSS to fulfill various business licenses. Business establishment permits and business operational permits can be obtained more quickly through this OSS because OSS will help business owners with mechanisms to perform committees to permit requirements for a business.

Secondly, facilitating business actors, OSS will reduce business actors in any case related to licensing of businesses run (Arrum, 2019). For example, with this OSS, business actors can more easily connect to all stakeholders so that business actors can get permission faster and more securely. Not only that, but you'll also get perks in other respects. Like for example, in reporting about a permit. In addition, it will also get troubleshooting regarding licensing issues in one place. So with this OSS, all facilities regarding licensing can be obtained more easily. Facilities can also be obtained in terms of data storage licensing. This licensing data will be stored in one attempted identity, commonly referred to as NIB (Sanjoyo et al., 2020).

With the application of licensing application services through this OSS system, business actors are expected to no longer go to various ministries/state institutions or regional device organizations to take care of permits gradually. Thus, business actors immediately start their activities while completing 
documents to implement other location permits. Building permits, environmental permits, and other obligations such as the Indonesian National Standard.OSS is designed to be integrated with the Directorate General of General Legal Administration of the Ministry of Law and Human Rights and the Directorate General of Taxation of the Ministry of Finance. This OSS is also planned as a means of information and for complaints and complaints. Oss is nothing new. Previously the term OSS was better known for the abbreviation One-Stop Service which the government proposed in the early 2000s.

The Investment Coordinating Board has organized various studies and seminars since the reign of President Soesilo Bambang Yudhoyono. Presidential Instruction No. 3 of 2006 instructing 24 Ministers, Heads of Non-Departmental Institutions, and Regional Heads (Regents/Mayors) to take the necessary measures to improve a more conducive investment climate. One-Stop Service's journey was then hit with challenges. Starting from ministerial regulations that are not in sync with presidential laws to the reluctance of the local government to implement them that strict sanctions by the government do not accompany.

The use of OSS, of course, requires procedures to be done with the proper steps. Various strategies can be carried out through precisely sequential stages. For example, we can use OSS in the next scene, creating a user ID. After creating a user ID, the user can log in to the OSS system by using the user ID. After that, it can fill in the data to obtain the Attempted Master Number (NIB). Those who have just had a business license must get an essential permit first. As for businesses that have been established, they can continue the process to get new business permits that have not been owned while extending existing business permits.

The use of Online Single Submission is proven to provide more optimal benefits. Similarly, a company decided to use the right payroll system by switching to Jojo Payroll. Through this product, of course, the company's payroll can run automatically and more effectively and efficiently so that the work of the company's financial team is also more maximal.

\section{Implementation of Location Permit Service Through Online Single Submission System at Bogor City Land Office}

One-Stop Service adalah unit kerja di tingkat Kota/Kabupaten yang secara eksplisit menyediakan layanan untuk memproses dokumen publik, terutama proses bisnis dan investor (Sutedi, 2009). However, business and investment licensing can cause negative connotations if too many convoluted, long-lasting, and expensive permits. To remove such purposes can be simplified through one-door (integrated) Service through a technical licensing unit (UPT) or Technical Service Office (KPT). This policy can cut the administrative burden for local governments and make it easier for businesses to access resources for business development.

Bogor City Integrated Service Office can carry out its duties and functions in integrated licensing since the issuance of Bogor Mayor Regulation No. 13 of 2019, which regulates licensing issues in Bogor City. Until now, the number of services held reached 52 permits/services. During the last two years, the number of permit applicants in Bogor City has been relatively often submitted with building permits (IMB), Interference permit (HO), industrial business license, industry listing applicants, trade business license, and location permits. The amount of interest in submissions to the type of permits above is not independent of the primary function of Kota Bogor as an orderly city of trade and service administration. After approximately two years of operation, it seems interesting to study how the Bogor City government implements one-stop Service in its territory, especially granting location permits.

Today, One-Stop Service is perfected into an Online Single Submission system that is an application used for all registration processes and business licensing applications and other licensing submissions included in the licensing Service according to Government Regulation No. 24, 2018. 
Accordingly, the Central Government establishes implementing the authority to grant Attempted Licensing as stipulated in this regulation and other related laws and regulations.

OSS is under the Coordinating Ministry for Economic Affairs and the Coordinating Board for Capital Security of the Republic of Indonesia. The legal basis for its establishment is Government Regulation No. 24 of 2018 on Licensing Services Trying to Integrate Electronically or Online Single Submission, further abbreviated as OSS. Simply put, OSS is an Attempted Licensing issued by the OSS Institution for and on behalf of the Minister, head of the institution, Governor, or Regent / Mayor to business actors through an integrated electronic system adhering to the concept of Electronic Service (EService) (Prayuda et al., 2020).

OSS is a web-based application that serves to help the process of filing complaints and licensing for the following enforcement process carried out by the role of decision-makers. This OSS web application provides attempted application data, existing licensing data, regional agency data, regional licensing data, and others (Arrum, 2019). OSS location permit is a system integrated electronically in the framework of attempted licensing services. This system was created to simplify and speed up the licensing process of structural reform (Farah \& Astuti, 2020).

Location permission services through OSS systems are closely related to internet technology. However, it must be realized that not all citizens who will do business (become business people) can use internet technology or have considerable capital. In addition, business people do not have enough time related to the convoluted licensing bureaucracy. (Sanjoyo et al., 2020)

Since implementing system OSS, several permissions must be adjusted and integrated with the OSS system, one of which is Location Permissions. As a follow-up, the Minister of Agrarian Affairs and Spatial Planning / Head of the National Land Agency issued Regulation No. 14, 2018 on Location Permits. Location Permit is a permit granted to business actors to obtain land necessary for business licensing or their activities and also applies as a permit for the transfer of rights and to use the land for business purposes or activities. Location permit is a requirement to obtain land for investment purposes required Location Permit before business actors carry out land acquisition activities (Sutedi, 2009)

The application for the permit location must be taken care of immediately once the applicant company gets the Attempted Master Number (NIB). Not only location permits, but applicants also need to take care of environmental permits, business licenses, and operational/commercial permits. These four permits can be obtained directly if your company is established in a Special Economic Area (KEK), National Tourism Strategy Area (KSPN), Industrial Area (KI), and Free Port and Free Trade Area (KPBPB).

Based on data from the Central Statistics Agency (BPS) from the results of the 2016 Economic Census, there were 26.71 million companies in Indonesia from 22.73 million in 2018. There was an increase from 2018 to 2020 of $17.51 \%$ (Wibisana, 2018). The data shows the number of business people who want to build a company. Related to the construction of this company, business people need to pocket business license documents, including location permits. This is related to the land to be used for business activities as stipulated in the provisions of the Regulation of the Minister of Agrarian Affairs / Head of the National Land Agency No. 17 of 2019, which replaces the Regulation of the Minister of Agrarian Affairs and Spatial Planning / Head of the National Land Agency No. 14, 2018.

To obtain a Location Permit, business people need to follow the applicable provisions of Article 8 of the Regulation of the Minister of Agraria / Head of the National Land Agency No. 17 of 2019 related to the Procedures for Granting and Requirements. Business actors who have obtained permission/approval/registration or similar from authorized officials in the field of investment. Location Permits may also be granted without Commitment if the land of the business location meets specific criteria, as stipulated in Article 7 Paragraph (2) of the Regulation of the Minister of Agraria / Head of the National Land Agency No. 14 of 2018, among others: 
The location of the land or business activities is located in a place that has followed its designation under the Spatial Plan; or general spatial plans of urban areas; Land of business or activity locations are located in the position of particular economic areas, industrial estates, as well as free trade areas and free ports; and

The land of the business location or activity is the land that has been controlled by other Business Actors who have obtained a Location Permit and will be used by business actors.

Business Actors apply for location permit registration electronically through the OSS Institution. The OSS Institution then issues location Permits in a decision granting a Location Permit. In the case of Location Permits based on Commitments, Business Actors can only carry out land acquisition activities after the Location Permit is effectively valid at the designated location in the Land Technical Consideration Map. Furthermore, Business Actors must apply to fulfill the Location Permit Commitment no maximum of 10 days since the OSS Institution issued a Location Permit (Assegaf et al., 2019).

In another case with Location Permits without Commitment, location permits issued by OSS Institutions are effectively valid, and Business Actors can directly carry out land acquisition activities. Location Permits are granted for three years from when the Location Permit becomes effective. Acquisition of land by the Holder of the Location Permit must be completed within the time of the Location Permit. Location Permit Holders must report periodically every three months to the Head of Land Office regarding land acquisition that has been carried out based on the Location Permit. The implementation of the use of the land That has been obtained must be registered with the local Land Office for at least one year from the expiration of the Location Permit validity period(Hastuti, 2020)

Business people can register to obtain location permission by accessing the OSS page(Assegaf et al., 2019) The requirements that business actors must meet to take care of location permits before accessing the OSS page are as follows (Article 8 paragraph (4) per ministerial regulation No. 17 the Year 2019): Attempted Parent Number (NIB); Statement and request for the fulfillment of Location Permit Commitment; Map/sketch that contains the coordinates of the location limit requested; Proposal of business activity plan; Land area statement letter that has been controlled by Business Actors and other Business Actors who are 1 group.

In addition to these requirements, business actors must fulfill the location permit commitment in advance so that the location permit can be effective. However, suppose the land plan of the business location or activity meets one of the provisions of the exception to the fulfillment of the location permit commitment. In that case, the location permit can be effective without fulfilling the Commitment (Article 8 paragraph (3) per ministerial regulation No. 1 in 2019).

After implementing Online Single Submission (OSS), location permit policies and land technical considerations experienced changes in governance. The Ministry of Agrarian Affairs and Spatial Planning / Head of the National Land Agency issued Ministerial Regulation No. 14 of 2018 on Location Permit and Ministerial Regulation No. 15 of 2018 on Land Technical Considerations. There is a difference in the authority of granting location permits, which were previously issued by regents/mayors, governors, and ministers following their power to be published by OSS institutions based on the Commitment of business actors (Mayasari, 2019). Meanwhile, prospectively this encourages the acceleration of licensing efforts and synchronization of spatial and space utilization, supported by the policy of one map and one Data Indonesia.

The current legal rules related to location permits are the Regulation of the Minister of Agrarian Affairs and Spatial Planning / Head of the National Land Agency No. 17, 2019 and Government Regulation No. 24 of 2018 on Licensing Services Trying to Integrate Electronically. In the Regulation of the Minister and Government Regulations, location permits are defined as permits given to business actors to obtain land necessary for their business or activities and apply as a permit to transfer rights and use the land for business purposes or activities. 
Related to the Service of location permits through the OSS System, at the Bogor City Land Office, data obtained data on the number of location permit applications submitted by business actors in the form of business entities to obtain technical applications to the Bogor City Land Office in the period 2019 to 2020 as many as 7 (seven) applications. The details of the location permit submitted by the business actors consisted of 6 (six) applications for land use applications submitted for housing development and 1(one) application for location permits for the construction of malls, hotels, apartments, commercial and residential areas (Bogor City Land Office, 2021).

Based on interviews with Bogor city land officials [2021] obtained information that in its implementation, there are still many business actors who apply for location permits, not through the system OSS. This condition did not support the implementation of Computerized Land Activities (KKP), which is integrated against the application service system licensing Online Single Submission at the Bogor City Land Office. The difficulty accessing the OSS system to the KKP caused land office officials not to implement the rules in issuing location permits through the OSS system. These conditions impact the resulting products only made manually location permit maps, not digital products as required in the above regulations. In addition, new things arise about setting location permits in the provisions of Law No. 11 on Work Copyright, where the government can revoke location permits that violate the Regional Spatial Plan. Another problem, the mechanism of Service of the application for location permits through OSS at the Bogor City National Land Office, which is not all can be done through OSS. In addition, there are still special permits requiring direct interaction with relevant institutions, and there are still problems in integrating data coming from various ministries and institutions.

\section{Conclusion}

The government sets a licensing service policy through the Online Single Submission system to improve the national economy. Service policy through the OSS system can affect the growth of the business world, which has been complaining about the length of time and bureaucratic chain in issuing attempted licensing, including in the Service of issuing location permits. Implementing location permit application services through the online single submission system at the Bogor City Land Office is not optimal because special permits require direct interaction with the relevant agencies. This leads to difficult access to the Online Single Submission system that has not been supported by the availability of adequate land computerized equipment or devices in the Land Office in the process of issuing location permits integrated on the Online Single Submission system. To provide troubleshooting of location permit application services through the Online Single Submission system at the Land Office, efforts are needed to solve it. The government's solution efforts are the need for appropriate technical arrangements related to implementing location permit services that are integrated electronically with all ministries/state institutions to local governments in Indonesia. In computerized ground activities integrated into the Online Single Submission System Service.

\section{Reference}

Arrum, D. A. (2019). Kepastian Hukum Dalam Perizinan Berusaha Terintegrasi Secara Elektronik (Online Single Submission) di Indonesia. Jurist-Diction, 2(5), 1631. https://doi.org/10.20473/jd.v2i5.15222

Asiyah, N. (2017). Strategi Implementasi Perizinan Dan Sanksi Administratif Sebagai Pembatasan Terhadap Kebebasan Bertindak. Jurnal Hukum Samudra Keadilan, 12(1), 123-135.

Assegaf, M. I. F., Juliani, H., \& Sa'adah, N. (2019). Pelaksanaan Online Single Submission (OSS) Dalam Rangka Percepatan Perizinan Berusaha Di Dinas Penanaman Modal Dan Pelayanan Terpadu Satu Pintu (DPMPTSP) Jawa Tengah. Jurnal Hukum Diponegoro, 8(2), 1328-1342. 
Farah, S., \& Astuti, R. S. (2020). Inovasi Sistem Perizinan Usaha Mikro Melalui OSS (Online Single Submission) Pada Dinas Penanaman Modal dan Pelayanan Terpadu Satu Pintu (Dpm- Ptsp) Kota Semarang. Journal of Public Policy and Management Review, 10(1).

Hasni. (2008). Hukum Penaataan Ruang dan Penatagunaan Tanah. Rajawali.

Hastuti, S. D. (2020). Pengendalian Pemanfaatan Ruang Melalui Izin Lokasi Dalam Rangka Perolehan Tanah Yang Diperlukan Usaha. Jurist-Diction, 3(3), 1099. https://doi.org/10.20473/ jd.v3i3.18640

Mayasari, I. (2019). Evaluasi Kebijakan Izin Lokasi Dan Pertimbangan Teknis Pertanahan Pasca Penerapan Online Single Submission. Jurnal Rechts Vinding: Media Pembinaan Hukum Nasional, 8(3), 403. https://doi.org/10.33331/rechtsvinding.v8i3.348

Prasetio, E., Isnaini, I., \& Adam, A. (2021). Analisis Kualitas Pelayanan Perizinan melalui Online Single Submission pada Dinas Penanaman Modal Dan Pelayanan Perizinan Terpadu Satu Pintu Kota Binjai. Perspektif, 10(2), 710-727. https://doi.org/10.31289/perspektif.v10i2.5176

Prayuda, D. K., Rahman, A., Rizky, G. N., \& Rifqi, A. M. (2020). Kualitas Perizinan Berbasis Open Single Submissionpada Dinas Penanaman Modal dan Pelayanan Terpadu Satu Pintu Kota Samarinda. Journal of Policy \& Bureaucracy Management, 1(1), 34-43.

Sanjoyo, S., Sapriani, S., Setiawan, A., \& ... (2020). Perizinan Berusaha Melalui Online Single Submission Sebagai Ketaatan Hukum Dalam Rangka Meningkatkan Investasi. Borneo Law Review ..., 4(1), 64-78. http://180.250.193.171/index.php/bolrev/article/viewFile/1397/955

Santoso, U. (2012). Pengantar Hukum Penataan Ruang. Airlangga University Press.

Setiadi, T., Rohaedi, E., \& Wajihuddin, M. (2021). Penerbitan Permohonan Perizinan Berusaha Melalui Sistem Online Single Submission. Pakuan Law Review, 07(1), 74-85.

Spelt, N., Ten BergeJ, .B.J.M, \& Hadjon, P. M. (1993). Hukum Perizinan. Yuridika:, 86.

Sutedi, A. (2009). Hukum Perizinan dalam Sektor Pelayanan Publik. Sinar Grafika.

Wibisana, A. G. (2018). Pengelolaan Lingkungan Melalui Izin Terintegrasi Dan Berantai: Sebuah Perbandingan Atas Perizinan Lingkungan Di Berbagai Negara. Jurnal Hukum \& Pembangunan, $48(2), 222-255$.

\section{Copyrights}

Copyright for this article is retained by the author(s), with first publication rights granted to the journal.

This is an open-access article distributed under the terms and conditions of the Creative Commons Attribution license (http://creativecommons.org/licenses/by/4.0/). 